\title{
Brain-derived neurotrophic factor, epigenetics in stroke skeletal muscle, and exercise training
}

Alice S. Ryan, PhD, Huichun Xu, PhD, Frederick M. Ivey, PhD, Richard F. Macko, MD, and Charlene E. Hafer-Macko, MD

Neurol Genet 2019;5:e331. doi:10.1212/NXG.0000000000000331

\author{
Correspondence \\ Dr. Ryan \\ aryan@som.umaryland.edu
}

\section{Abstract}

\section{Objective}

(1) To compare paretic (P) vs nonparetic (NP) skeletal muscle brain-derived neurotrophic factor (BDNF) and the effects of resistive training (RT) on systemic and skeletal muscle BDNF mRNA expression in stroke; and (2) to compare the DNA methylation profile for BDNF and BDNFAS (BDNF antisense RNA) between $P$ and NP muscle and the effects of aerobic exercise training (AEX) on DNA methylation in stroke.

\section{Methods}

In this longitudinal investigation, participants (50-76 years) with chronic stroke underwent a fasting blood draw, a 12-week ( $3 \times$ /week) RT intervention $(n=16)$, and repeated bilateral vastus lateralis muscle tissue biopsies $(\mathrm{n}=10)$ with BDNF expression determined by RT-PCR. Five stroke survivors completed 6 months of AEX ( $3 \times /$ week) and had bilateral muscle biopsies. DNA methylation status in gene BDNF and BDNFAS was assessed by Illumina 450k methylation array.

\section{Results}

P muscle had $\sim 45 \%$ lower BDNF mRNA expression than NP muscle (6.79 \pm 1.30 vs $10.52 \pm$ 2.06 arbitrary units $[\mathrm{AU}], p<0.05)$, and $\mathrm{P}$ muscle exhibited differential methylation status in the DNA sequences of BDNF (3 CpG [5'-C-phosphate-G-3'] sites, $p=0.016-0.044$ ) and BDNFAS ( 1 CpG site, $p=0.016$ ) compared to NP. Plasma BDNF and muscle BDNF messenger RNA (mRNA) expression did not significantly change after RT. BDNFAS DNA methylation increased after AEX in P relative to NP muscle $(p=0.017)$.

\section{Conclusions}

This is the first evidence that stroke hemiparesis reduces BDNF skeletal muscle expression, with our findings identifying methylation alterations on the DNA sequence of BDNF and BDNFAS gene. Preliminary results further indicate that AEX increases methylation in BDNFAS gene, which presumably could regulate the expression of BDNF.

\footnotetext{
From the VA Maryland Health Care System, Research Service, Department of Medicine, Division of Gerontology and Geriatric Medicine, Department of Neurology, at the University of Maryland School of Medicine, and the Baltimore Geriatric Research, Education and Clinical Center (GRECC), MD.

Funding information and disclosures are provided at the end of the article. Full disclosure form information provided by the authors is available with the full text of this article at Neurology.org/NG. 


\section{Glossary}

AEX = aerobic exercise training; $\mathbf{B D N F}=$ brain-derived neurotrophic factor; $\mathbf{B D N F A S}=\mathrm{BDNF}$ Antisense RNA; NP = nonparetic; $\mathbf{P}=$ paretic; $\mathbf{R T}=$ resistive training.

It is well established that stroke leads to long-term disability and cognitive dysfunction. Physical activity improves motor and cognitive ability perhaps, in part, due to enhanced neurotrophic factor signaling. Brain-derived neurotrophic factor (BDNF) is a protein that promotes neuroplasticity, including the growth and survival of neurons, regulation of axonal and dendritic branching, and synaptic transmission. ${ }^{1}$ BDNF may mediate the improvement in cognition after acute exercise. ${ }^{2}$ Yet, it is unknown whether BDNF changes with exercise training in neurologic conditions, such as chronic stroke. We hypothesize that BDNF is involved in the skeletal muscle changes poststroke and that exercise (resistive training [RT] or aerobic exercise training $[\mathrm{AEX}]$ ) exerts beneficial effects through epigenetic regulation of BDNF expression. Therefore, in this 2-part preliminary investigation, we sought to compare paretic $(\mathrm{P})$ vs nonparetic (NP) skeletal muscle BDNF and the effects of RT on systemic and skeletal muscle BDNF mRNA expression in stroke and to compare the DNA methylation profile for BDNF and BDNF antisense RNA (BDNFAS) between $\mathrm{P}$ and NP muscle and assess the effects of AEX on DNA methylation in stroke.

\section{Methods}

Twenty-one participants who had a prior stroke aged 43-81 years with body mass index between 21 and $39 \mathrm{~kg} / \mathrm{m}^{2}$ who had mild-to-moderate hemiparetic gait deficits and completed conventional rehabilitation therapy provided written informed consent to participate in this longitudinal investigation at the Baltimore Veterans Affairs Medical Center and the University of Maryland School of Medicine. Evaluations included medical history, physical examination, and fasting blood profile. Participants with stroke were excluded for unstable angina, congestive heart failure (NYHA II), severe peripheral arterial disease, major poststroke depression, dementia, severe receptive aphasia, and orthopedic or chronic pain conditions. All methods and procedures were approved by the institutional review board of the University of Maryland and the VA R\&D Committee.

\section{Tests}

Height, weight, fat mass, lean tissue mass, and \%body fat were determined by dual-energy $x$-ray absorptiometry (Prodigy LUNAR GE version 7.53.002). Exercise testing with opencircuit spirometry was conducted to measure peak aerobic capacity $\left(\mathrm{VO}_{2}\right.$ peak) using a graded treadmill test. Onerepetition maximum strength tests assessed leg press and leg extension strength of each leg (Keiser, Fresno, CA).

\section{Resistive training}

Participants trained $3 \times /$ week for 12 weeks, performing 2 sets of 20 unilateral repetitions on the leg press, leg extension, and leg curl machines (Keiser; pneumatic resistance, Fresno, CA) at every session. ${ }^{3}$

\section{Aerobic exercise training}

The progressive treadmill protocol consisted of three 40minute sessions per week at a target aerobic intensity of $60 \%-70 \%$ heart rate reserve performed over a 6-month training period. Training started at low intensity $(40 \%-50 \%$ heart rate reserve) for 10-20 minutes and gradually progressed to target levels. ${ }^{4}$

\section{Plasma and muscle analyses}

Plasma BDNF was measured in duplicate using Human BDNF Emax ImmunoAssay Kit. Vastus lateralis biopsies of the $\mathrm{P}$ and NP muscle were performed under local anesthesia after a 12-hour fast at baseline and after RT $(\mathrm{n}=10)$ and after $\operatorname{AEX}(n=5), 24-36$ hours after the last bout of exercise. Muscle was immediately freeze-clamped and stored at $-80^{\circ} \mathrm{C}$. RNA extraction, reverse transcription, and quantitative realtime PCR for gene expression ${ }^{3}$ of BDNF was conducted. The Illumina 450k methylation array was used for DNA methylation according to manufacturer's protocol. Briefly, DNA purified from muscle was bisulfite-converted using EZ-96 DNA methylation kit (D5004, Zymo Research), amplified, and then enzymatically fragmented followed by hybridization with the $450 \mathrm{k}$ array and fluorescent staining.

\section{Statistical analyses}

Baseline BDNF levels between P and NP thigh muscle was determined using paired Student $t$ tests. Changes were assessed using repeated measures analysis of variance using SPSS 22.0. The 450k array image file (IDAT files) processed using the minfi package to calculate intensity and perform Subset-quantile within array normalization method was used to reduce the technical variability between type I and type II assay designs. Methylation scores are calculated as $\beta$ values, ranging from 0 (totally unmethylated) to 1 (totally methylated). $M$ values were derived as logit ( $\beta$ ), which have properties suitable for statistical tests. Differential methylation between $\mathrm{P}$ and NP thigh muscle and between post- and preAEX thigh muscle was evaluated by paired Student $t$ test on the $\mathrm{M}$ values. Data are presented as means \pm SEM. $p$ values $<$ 0.05 are statistically significant.

\section{Data availability statement}

De-identified data and the study protocol may be available. More information regarding the data is available from the corresponding author on reasonable request.

\section{Clinical trials identifiers}

NCT02347995, NCT00387712, NCT00891514. 
Figure $1 \mathrm{P}$ and NP skeletal muscle brain-derived neurotrophic factor mRNA expression

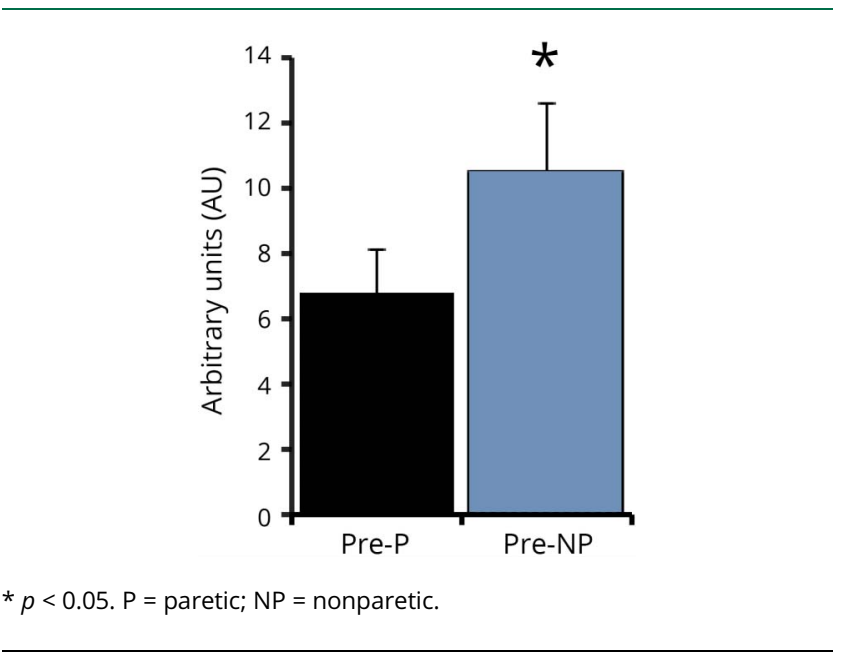

\section{Results}

\section{Resistive training}

Leg press strength increased by $26 \%$ for the $\mathrm{P}$ leg (304 \pm 40 vs $363 \pm 41 \mathrm{lbs}$ derived from pneumatic resistance equipment) and $25 \%$ for NP leg (449 \pm 36 vs $560 \pm 33 \mathrm{lbs}$ ) (both $p<0.0001$ ) with RT. Leg extension strength increased by $47 \%$ and $25 \%$ (P: $57 \pm 10$ vs $84 \pm 11 \mathrm{lbs}$, NP: $113 \pm 10$ vs $141 \pm 9$ lbs respectively, both $p<0.0001)$. Plasma BDNF protein increased by $25 \%$ with RT but this was not significant $(0.64 \pm 0.08$ vs $0.87 \pm 0.20 \mathrm{ng} /$ $\mathrm{mL})$. P muscle has $\sim 45 \%$ lower BDNF mRNA expression $(p<$ 0.05 ) than NP muscle (figure 1). Skeletal muscle BDNF mRNA did not change with RT (P: $7.21 \pm 1.38$ vs $7.06 \pm 1.85 \mathrm{AU}$ and NP: $11.39 \pm 2.12$ vs $7.84 \pm 1.32 \mathrm{AU})$.

\section{Aerobic exercise training}

$\mathrm{VO}_{2}$ peak increased by $18 \%$ with $\operatorname{AEX}(22.5 \pm 2.5$ vs $26.6 \pm$ 3.5, $p<0.05)$. P and NP muscle have differential methylation status for DNA sequences of BDNF ( $3 \mathrm{CpG}$ sites, $p=0.016$ to 0.044 ) and BDNFAS (1 CpG site, $p=0.016$ ) (table 1) at baseline (prior to exercise training). Table 1 also provides the $\beta$ coefficients and the probe set ID. After AEX, there were significant changes in methylation of $\mathrm{P}$ muscle at $2 \mathrm{CpG}$ sites (table 2). DNA methylation in BDNFAS increased in $\mathrm{P}$

Table 1 Baseline P and NP skeletal muscle BDNF methylation

\begin{tabular}{lllll}
\hline Probeset ID & Gene & $\boldsymbol{\beta}$ (NP muscle) & $\boldsymbol{\beta}$ (P muscle) & $\boldsymbol{p}$ Value \\
\hline Cg22830701 & BDNFAS & 0.069 & 0.042 & 0.016 \\
\hline Cg23426002 & BDNF & 0.934 & 0.913 & 0.016 \\
\hline Cg20108357 & BDNF & 0.869 & 0.900 & 0.028 \\
\hline Cg06260077 & BDNF & 0.123 & 0.144 & 0.044 \\
\hline
\end{tabular}

Abbreviations: $B D N F=$ brain-derived neurotrophic factor; BDNFAS $=$ BDNF Antisense RNA; $\mathrm{P}=$ paretic; $\mathrm{NP}=$ nonparetic.
Table 2 Paretic skeletal muscle BDNF methylation after AEX

\begin{tabular}{lllll}
\hline Probeset ID & Gene & $\boldsymbol{\beta}$ (pre-AEX) & $\boldsymbol{\beta}$ (post-AEX) & $\boldsymbol{p}$ Value \\
\hline $\operatorname{cg} 22830701$ & BDNFAS & 0.042 & 0.068 & 0.017 \\
\hline $\operatorname{cg} 22973087$ & $\begin{array}{l}\text { BDNFAS/ } \\
\text { LIN7C }\end{array}$ & 0.029 & 0.039 & 0.019 \\
\hline
\end{tabular}

Abbreviations: $\mathrm{AEX}=$ aerobic exercise training; $\mathrm{BDNFAS}=\mathrm{BDNF}$ antisense RNA.

relative to NP muscle ( $p=0.017$, figure 2$)$. DNA methylation in BDNFAS did not change significantly in NP muscle.

\section{Discussion}

Our results provide the first preliminary evidence of reduced BDNF expression in $\mathrm{P}$ skeletal muscle as well as differential methylation status for BDNF and BDNFAS between $\mathrm{P}$ and NP muscle and suggests that AEX modulates methylation for BDNF in $\mathrm{P}$ muscle. We are unaware of any studies examining BDNF expression in skeletal muscle of stroke patients, or changes with exercise training in this population. The difference in BDNF expression between the P and NP limb in both gene expression and methylation provide important evidence for epigenetic modifications after stroke.

There is limited work in human skeletal muscle for BDNF. Acute exercise increases BDNF mRNA and protein expression in young healthy men. ${ }^{5}$ Evidence remains inconclusive regarding the effectiveness of exercise training on serum BDNF. Our results indicate that circulating BDNF did not change after RT. Other studies report that 8-12 weeks of RT either increase $^{6}$ or do not change ${ }^{7}$ serum BDNF in older adults. Postulated mechanisms for improved cognition with exercise includes increased blood flow or oxidative stress leading to increased endothelial function and release of BDNF from the brain microvascular endothelial cells. ${ }^{2}$ Indeed, we have shown

Figure 2 DNA \%methylation for cg22830701 BDNFAS after aerobic exercise training, $n=5$

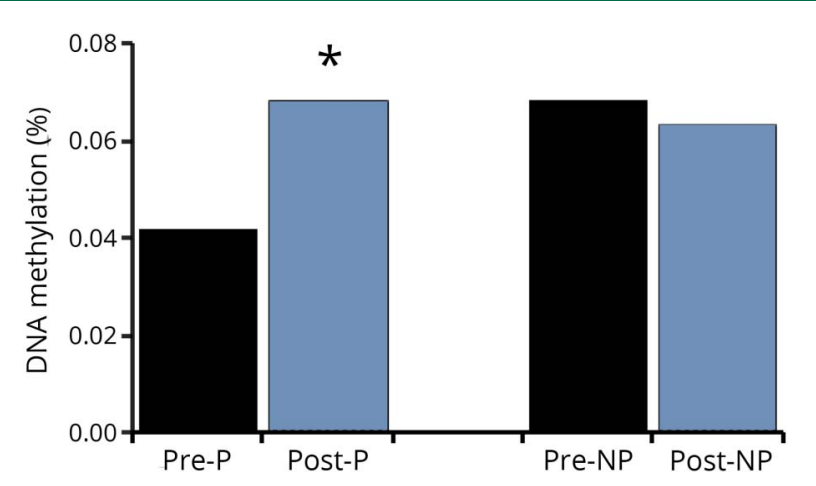

${ }^{*} p<0.05 . \mathrm{P}=$ paretic; $\mathrm{NP}=$ nonparetic. 
increased cerebral vasomotor reactivity after aerobic training in chronic stroke ${ }^{4}$ providing evidence of changes in cerebral blood flow, which could potentially influence BDNF levels.

Epigenetic regulation of numerous genes, specifically methylation at the BDNF gene, was reported in a recent systematic review related to neurodegenerative diseases. ${ }^{8}$ Peripheral BDNF methylation is promoted as a surrogate for central BDNF methylation, given the direct relationships observed between BDNF promoter methylations in the hippocampus and quadriceps tissue of patients with bipolar disorder. ${ }^{9}$ Patients with mild depressive disorder not only have higher BDNF promoter methylation than healthy controls but also thinning of several cortical regions of the brain. The latter finding is inversely correlated with BDNF promoter methylation. ${ }^{10}$ We are unaware of studies in chronic stroke. Our finding that methylation decreased the gene expression of BDNFAS supports an increase in BDNF.

Limitations of the current trial include the relatively small sample size and limited human muscle sample available for analysis. In addition, a broader analysis on genome-wide DNA methylation and transcription profile changes in $\mathrm{P}$ vs NP muscles would be informative in future studies. However, the current studies were highly controlled and included supervised exercise training programs and standardization of muscle biopsy timing and conditions and novel with respect to skeletal muscle methylation in chronic stroke. Our earlier work has established that $\mathrm{P}$ muscle after chronic stroke has metabolic and structural differences relative to the NP muscle. ${ }^{1-15}$ The clinical relevance of the difference in DNA methylation in P vs NP muscle and following exercise training cannot be determined in this preliminary investigation.

A larger randomized controlled trial is necessary to establish the effects of exercise on BDNF methylation and other epigenetic modifications in stroke skeletal muscle. Future research could also examine changes in epigenetics with exercise training and whether training-induced changes associate with improved cognitive ability after stroke.

\section{Study funding}

This study was supported by funds from VA RR\&D Senior Research Career Scientist Award (ASR), NIH grants R01AG030075, VA Merit Awards, Claude D. Pepper Older Americans Independence Center (P30AG028747), the Baltimore VA Geriatric Research, Education, and Clinical Center (GRECC).

\section{Disclosure}

Disclosures available: Neurology.org/NG.

\section{Publication history}

Received by Neurology: Genetics January 24, 2019. Accepted in final form March 25, 2019.

\begin{tabular}{llll} 
Appendix & Authors & & \\
\hline Name & Location & Role & Contribution \\
\hline $\begin{array}{l}\text { Alice S. } \\
\text { Ryan, PhD }\end{array}$ & $\begin{array}{l}\text { University of } \\
\text { Maryland, } \\
\text { Baltimore }\end{array}$ & Author & $\begin{array}{l}\text { Design and conceptualized } \\
\text { study; performed and } \\
\text { collected the data; performed } \\
\text { statistical analysis; drafted } \\
\text { the manuscript for } \\
\text { intellectual content }\end{array}$ \\
\hline $\begin{array}{l}\text { Huichun } \\
\text { Pu, MD, }\end{array}$ & $\begin{array}{l}\text { University of } \\
\text { Maryland, } \\
\text { Baltimore }\end{array}$ & Author & $\begin{array}{l}\text { Performed statistical analysis } \\
\text { and revised the manuscript }\end{array}$ \\
\hline $\begin{array}{l}\text { Frederick } \\
\text { Ivey, PhD }\end{array}$ & $\begin{array}{l}\text { University of } \\
\text { Maryland, } \\
\text { Baltimore }\end{array}$ & Author & $\begin{array}{l}\text { Performed and collected the } \\
\text { data; revised the manuscript }\end{array}$ \\
\hline $\begin{array}{l}\text { Richard } \\
\text { Macko, MD }\end{array}$ & $\begin{array}{l}\text { University of } \\
\text { Maryland, } \\
\text { Baltimore }\end{array}$ & Author & Revised the manuscript \\
\hline $\begin{array}{l}\text { Charlene } \\
\text { Hafer- } \\
\text { Macko, MD }\end{array}$ & $\begin{array}{l}\text { University of } \\
\text { Maryland, } \\
\text { Baltimore }\end{array}$ & Author & $\begin{array}{l}\text { Performed and collected the } \\
\text { data; revised the manuscript }\end{array}$ \\
\hline
\end{tabular}

\section{References}

1. Calabrese F, Rossetti AC, Racagni G, Gass P, Riva MA, Molteni R. Brain-derived neurotrophic factor: a bridge between inflammation and neuroplasticity. Front Cell Neurosci 2014;8:430.

2. Borror A. Brain-derived neurotrophic factor mediates cognitive improvements following acute exercise. Med Hypotheses 2017;106:1-5.

3. Ryan AS, Ivey FM, Prior S, Li G, Hafer-Macko C. Skeletal muscle hypertrophy and muscle myostatin reduction after resistive training in stroke survivors. Stroke 2011;42: 416-420.

4. Ivey FM, Ryan AS, Hafer-Macko CE, Macko RF. Improved cerebral vasomotor reactivity after exercise training in hemiparetic stroke survivors. Stroke $2011 ; 42$ : 1994-2000.

5. Matthews VB, Aström $\mathrm{MB}$, Chan $\mathrm{MH}$, et al. Brain-derived neurotrophic factor is produced by skeletal muscle cells in response to contraction and enhances fat oxidation via activation of AMP-activated protein kinase. Diabetologia 2009;52: 1409-1418.

6. Forti LN, Van Roie E, Njemini R, et al. Dose-and gender-specific effects of resistance training on circulating levels of brain derived neurotrophic factor (BDNF) in community-dwelling older adults. Exp Gerontol 2015;70: 144-149.

7. Walsh JJ, Scribbans TD, Bentley RF, Kellawan JM, Gurd B, Tschakovsky ME. Neurotrophic growth factor responses to lower body resistance training in older adults. Appl Physiol Nutr Metab 2016;41:315-323.

8. Wen KX, Miliç J, El-Khodor B, et al. The role of DNA methylation and histone modifications in neurodegenerative diseases: a systematic review. PLoS One 2016;11: e0167201

9. Stenz L, Zewdie S, Laforge-Escarra T, et al. BDNF promoter I methylation correlates between post-mortem human peripheral and brain tissues. Neurosci Res 2015;91: $1-7$.

10. Na KS, Won E, Kang J, et al. Brain-derived neurotrophic factor promoter methylation and cortical thickness in recurrent major depressive disorder. Sci Rep 2016; $6: 21089$

11. Ryan AS, Dobrovolny CL, Smith GV, Silver KH, Macko RF. Hemiparetic muscle atrophy and increased intramuscular fat in stroke patients. Arch Phys Med Rehabil 2002;83:1703-1707.

12. Ryan AS, Ivey FM, Serra MC, Hartstein J, Hafer-Macko CE. Sarcopenia and physical function in middle-aged and older stroke survivors. Arch Phys Med Rehabil 2017;98: 495-499.

13. Ivey FM, Hafer-Macko CE, Ryan AS, Macko RF. Impaired leg vasodilatory function after stroke: adaptations with treadmill exercise training. Stroke 2010;41: 2913-2917.

14. Hafer-Macko CE, Yu S, Ryan AS, Ivey FM, Macko RF. Elevated tumor necrosis factoralpha in skeletal muscle after stroke. Stroke 2005;36:2021-2023.

15. De Deyne PG, Hafer-Macko CE, Ivey FM, Ryan AS, Macko RF. Muscle molecular phenotype after stroke is associated with gait speed. Muscle Nerve 2004; 30:209-215. 


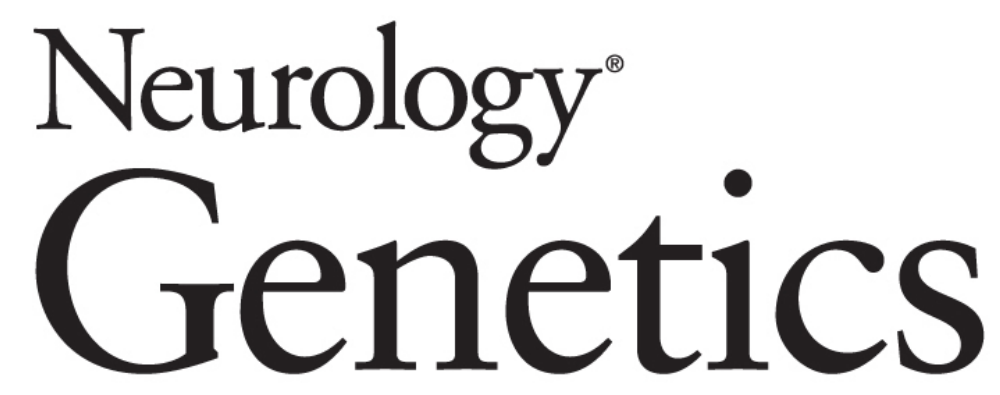

\section{Brain-derived neurotrophic factor, epigenetics in stroke skeletal muscle, and exercise training}

Alice S. Ryan, Huichun Xu, Frederick M. Ivey, et al.

Neurol Genet 2019;5;

DOI 10.1212/NXG.0000000000000331

This information is current as of May 1, 2019

\section{Updated Information \& Services}

\section{References}

Subspecialty Collections

Permissions \& Licensing

Reprints including high resolution figures, can be found at: http://ng.neurology.org/content/5/3/e331.full.html

This article cites 15 articles, 4 of which you can access for free at: http://ng.neurology.org/content/5/3/e331.full.html\#\#ref-list-1

This article, along with others on similar topics, appears in the following collection(s):

All Cerebrovascular disease/Stroke

http://ng.neurology.org//cgi/collection/all_cerebrovascular_disease_str oke

All Rehabilitation

http://ng.neurology.org//cgi/collection/all_rehabilitation

Information about reproducing this article in parts (figures,tables) or in its entirety can be found online at:

http://ng.neurology.org/misc/about.xhtml\#permissions

Information about ordering reprints can be found online: http://ng.neurology.org/misc/addir.xhtml\#reprintsus

Neurol Genet is an official journal of the American Academy of Neurology. Published since April 2015, it is an open-access, online-only, continuous publication journal. Copyright Copyright ( 2019 The Author(s). Published by Wolters Kluwer Health, Inc. on behalf of the American Academy of Neurology.. All rights reserved. Online ISSN: 2376-7839.

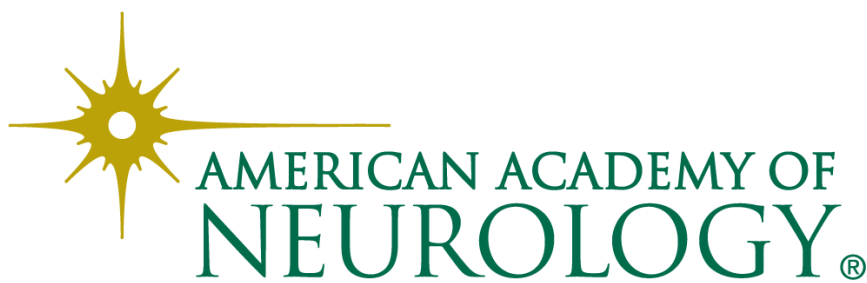

